\title{
Assessing the potential of calcium-based artificial ocean alkalinization to mitigate rising atmospheric $\mathrm{CO}_{2}$ and ocean acidification
}

\author{
Tatiana Ilyina, ${ }^{1}$ Dieter Wolf-Gladrow, ${ }^{2}$ Guy Munhoven, ${ }^{3}$ and Christoph Heinze $e^{4,5,6}$
}

Received 13 September 2013; revised 30 October 2013; accepted 31 October 2013; published 19 November 2013.

[1] Enhancement of ocean alkalinity using calcium compounds, e.g., lime has been proposed to mitigate further increase of atmospheric $\mathrm{CO}_{2}$ and ocean acidification due to anthropogenic $\mathrm{CO}_{2}$ emissions. Using a global model, we show that such alkalinization has the potential to preserve $\mathrm{pH}$ and the saturation state of carbonate minerals at close to today's values. Effects of alkalinization persist after termination: Atmospheric $\mathrm{CO}_{2}$ and $\mathrm{pH}$ do not return to unmitigated levels. Only scenarios in which large amounts of alkalinity (i.e., in a ratio of 2:1 with respect to emitted $\mathrm{CO}_{2}$ ) are added over large ocean areas can boost oceanic $\mathrm{CO}_{2}$ uptake sufficiently to avoid further ocean acidification on the global scale, thereby elevating some key biogeochemical parameters, e.g., $\mathrm{pH}$ significantly above preindustrial levels. Smaller-scale alkalinization could counteract ocean acidification on a subregional or even local scale, e.g., in upwelling systems. The decrease of atmospheric $\mathrm{CO}_{2}$ would then be a small side effect. Citation: Ilyina, T., D. Wolf-Gladrow, G. Munhoven, and C. Heinze (2013), Assessing the potential of calcium-based artificial ocean alkalinization to mitigate rising atmospheric $\mathrm{CO}_{2}$ and ocean acidification, Geophys. Res. Lett., 40, 5909-5914, doi:10.1002/2013GL057981.

\section{Introduction}

[2] Various geoengineering schemes of carbon dioxide removal (CDR) from the atmosphere have been proposed as additional means to keep growing greenhouse gas concentrations at bay until substantial emission reductions are realized [Royal Society, 2009; Intergovernmental Panel on Climate Change (IPCC), 2005]. One of the CDR methods is enhanced weathering - a process in which large amounts of silicate [Köhler et al., 2010; Schuiling and Krijgsman, 2006] or carbonate rocks [Caldeira and Rau, 2000; Harvey, 2008; Kheshgi, 1995; Rau, 2011; Rau and Caldeira, 1999;] are processed, grinded, and dispersed on land or ocean. In the

Additional supporting information may be found in the online version of this article.

${ }^{1}$ Max Planck Institute for Meteorology, Hamburg, Germany.

${ }^{2}$ Alfred Wegener Institute, Helmholtz Centre for Polar and Marine Research, Bremerhaven, Germany.

${ }^{3}$ Department of Astrophysics, Geophysics and Oceanography, University of Liège, Liège, Belgium.

${ }^{4}$ Geophysical Institute, University of Bergen, Bergen, Norway.

${ }^{5}$ Bjerknes Centre for Climate Research, Bergen, Norway.

${ }^{6}$ Uni Climate, Uni Research AS, Bergen, Norway.

Corresponding author: T. Ilyina, Max Planck Institute for Meteorology, Bundesstraße 53, DE-20146 Hamburg, Germany. (tatiana.ilyina@mpimet. mpg.de)

(C2013. American Geophysical Union. All Rights Reserved. 0094-8276/13/10.1002/2013GL057981 ocean, enhanced weathering would increase its total alkalinity (TA) characterized by the excess of proton acceptors (mainly bicarbonate and carbonate ions) over proton donors [Wolf-Gladrow et al., 2007]. The net result of such artificial ocean alkalinization will be an increase of the seawater capacity to absorb and store carbon. This mimics naturally occurring reactions and accelerates processes that would otherwise remove $\mathrm{CO}_{2}$ only on time scales of tens to hundreds of thousands of years [Archer, 2005]. An increase in TA would also alter seawater constituents so that its acidity decreases. Thus, in contrast to direct sequestration of carbon into the deep ocean [Ridgwell et al., 2011] alkalinity enhancement, along with a drawdown of atmospheric $\mathrm{CO}_{2}$, would also drive ocean $\mathrm{pH}$ and the saturation state of $\mathrm{CaCO}_{3}$ (referred to as $\Omega$ ) to higher values thereby counteracting ongoing ocean acidification. Unmitigated, ocean acidification is likely to have diverse negative impacts on marine biodiversity, food webs, and ecosystems including decrease in calcification rates or changes in reproduction and physiology observed in some marine organisms [Gattuso and Hansson, 2011].

[3] Variants of increasing TA via ocean-based enhanced weathering using calcium compounds can be realized by adding quick lime $(\mathrm{CaO})$, lime (calcium hydroxide, $\left.\mathrm{Ca}(\mathrm{OH})_{2}\right)$, or calcium carbonate $\left(\mathrm{CaCO}_{3}\right)$. Quick lime will react with water and form calcium hydroxide that will readily dissociate into $\mathrm{Ca}^{2+}$ and $2 \mathrm{OH}^{-}$, i.e., yielding the same ions as if adding lime. $\mathrm{CaCO}_{3}$ can dissociate into $\mathrm{Ca}^{2+}$ and $\mathrm{CO}_{3}{ }^{2-}$ if the aqueous solution is undersaturated (i.e., $\Omega<1$ ) with respect to the mineral phase (calcite, aragonite) of the added material. The surface ocean is currently supersaturated with respect to aragonite and calcite $(\Omega>1)$ except for a few locations (some upwelling regions or close to strong $\mathrm{CO}_{2}$ sources near volcanically active sites) [e.g., Feely et al., 2004]. Thus, $\mathrm{CaCO}_{3}$ has to be dissolved in an undersaturated solution before addition to the ocean. Whereas the resulting $\mathrm{Ca}^{2+}$ stays in solution (fully dissociated), the other dissociation products, namely $\mathrm{OH}^{-}$and $\mathrm{CO}_{3}{ }^{2-}$, further react with $\mathrm{H}^{+}$to form water or $\mathrm{HCO}_{3}{ }^{-}$and thereby increasing $\mathrm{pH}$ (lowering $\left[\mathrm{H}^{+}\right]$) and $\left[\mathrm{HCO}_{3}{ }^{-}\right]$and decreasing $\left[\mathrm{CO}_{2}\right]$. The addition of quick lime and lime has the same impact on TA: 1 mol of (quick) lime will add 2 mol to TA, while dissolved inorganic carbon $\left(\mathrm{TCO}_{2}\right)$ is not changing. When adding $1 \mathrm{~mol}$ $\mathrm{Ca}^{2+}$ and $1 \mathrm{~mol} \mathrm{CO}_{3}{ }^{2-}$ (i.e., when using $\mathrm{CaCO}_{3}$ ), TA increases by $2 \mathrm{~mol}$ and $\mathrm{TCO}_{2}$ by $1 \mathrm{~mol}$, and thus, this method has lower effectiveness for ocean $\mathrm{CO}_{2}$ sequestration than addition of (quick) lime. The addition of $\mathrm{Ca}^{2+}$ will result in small changes of the (high, about $10 \mathrm{mmol} \mathrm{L}^{-1}$ ) concentration of $\mathrm{Ca}^{2+}$ in the ocean and thus will have little effects on $\Omega$ via $\left[\mathrm{Ca}^{2+}\right]$; $\mathrm{Ca}^{2+}$ addition has an impact on $\Omega$ via changes in TA and thus $\left[\mathrm{CO}_{3}{ }^{2-}\right]$ [Zeebe and Wolf-Gladrow, 2001]. 

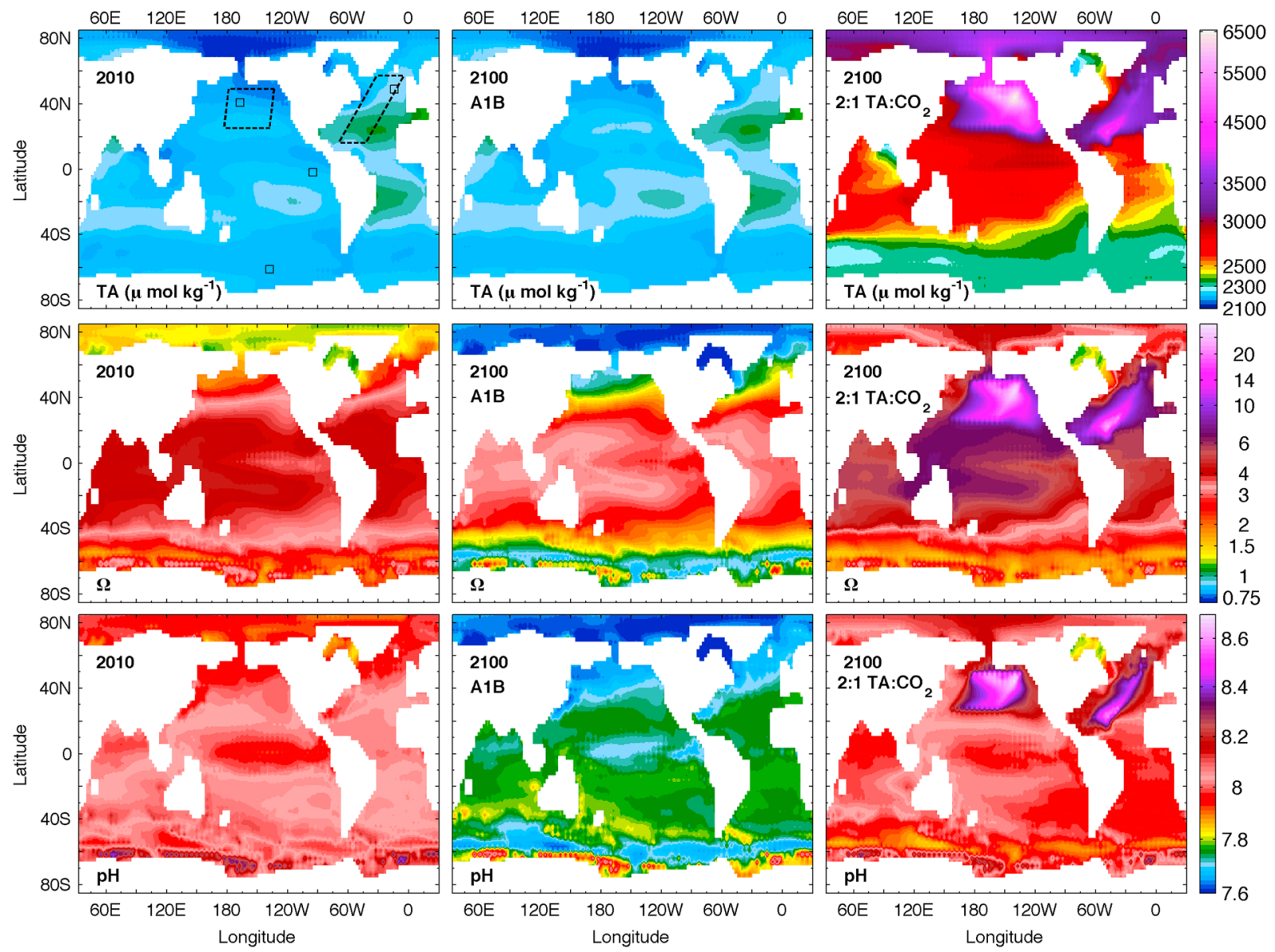

Figure 1. Surface maps of (top row) TA, (middle row) $\Omega$, and (bottom row) pH in the years 2010 (left column) and 2100 without artificial ocean alkalinization (middle column), and calculated in the large-scale alkalinization scenario with the molar ratio (of TA: $\mathrm{CO}_{2}$ ) 2:1 (right column). Sites of large-scale (dotted parallelograms) and subregional (solid squares) scenarios of alkalinity enhancement are shown in the upper left panel.

\section{Model Scenarios of Alkalinity Enhancement}

[4] We relate the amount of TA injected into the ocean to anthropogenic $\mathrm{CO}_{2}$ emissions. In all scenarios, for every mole of emitted $\mathrm{CO}_{2}$, we add a proportional flux of TA to the surface ocean in different locations (marked on Figure 1) or globally. We examine alkalinization scenarios bracketing the range of molar ratios of $0.2: 1 \mathrm{~mol} \mathrm{~mol}^{-1}$ (mole TA added per mole emitted fossil fuel $\mathrm{CO}_{2}$; later on referred to as TA: $\left.\mathrm{CO}_{2}\right)$ at the lower end and 2:1 at the higher end.

[5] We start ocean alkalinization in the year 2020, continuing a preindustrial model run (beginning in 1750) forced with historic emissions and the IPCC's A1B scenario until the year 2100 [IPCC, 2007] and gradually declining thereafter, until the end of the simulation period (being 3050 years). Alkalinity enhancement is assumed to continue for as long as fossil fuel $\mathrm{CO}_{2}$ is emitted in all model scenarios, except the one in which the effect of termination after 10 years is explored. Note that production of lime from $\mathrm{CaCO}_{3}$ liberates $\mathrm{CO}_{2}$ which should be compensated for [Kheshgi, 1995]. In order to reflect an increasing fossil fuel energy demand and therefore a decreasing effectiveness of $\mathrm{CO}_{2}$ sequestration, we also ran scenarios in which $\mathrm{TCO}_{2}$ is increased alongside with increasing TA.

[6] Projections of alkalinity enhancement have been calculated with the Hamburg Ocean Carbon Cycle model [Six and
Maier-Reimer, 1996; Ilyina et al., 2009]. The model includes the inorganic carbon cycle chemistry following Maier-Reimer and Hasselmann [1987] where TA is a prognostic variable expressed as the sum of carbonate and borate alkalinities, as well as water dissociation products. Simple ecosystem dynamics is based on the explicit parameterization of nutrients, phytoplankton and zooplankton, detritus, and dissolved organic matter in the water column. There is a diagenetic model for the bioturbated sediment zone (following Maier-Reimer et al. [2005]). The model is forced by prescribed and globally uniform weathering fluxes and uses an averaged flow field representative of the modern ocean (i.e., without climate feedback and changes in riverine fluxes). The model runs with a time step of 1 month and has a horizontal resolution of $3.5^{\circ}$. It has 22 vertical layers with thicknesses varying between $25 \mathrm{~m}$ at the surface and $700 \mathrm{~m}$ in the deep ocean.

\section{Mitigation Potential of Large-Scale Alkalinity Enhancement}

[7] Increasing seawater TA enhances oceanic uptake of $\mathrm{CO}_{2}$ from the atmosphere. In order to increase the contact area of the alkalized ocean with the air above, we first tested a model scenario in which alkalinity was distributed uniformly over the entire surface ocean (Figure S2 in the supporting 
Table 1. Summary of Modeled Alkalinization Scenarios and Their Resulting Effects on the Sea Surface $\mathrm{pH}$ and $\mathrm{Atmospheric} \mathrm{pCO}_{2}$ Compared to the A1B Scenario Without Alkalinity Enhancement

\begin{tabular}{|c|c|c|c|c|c|c|c|c|c|c|}
\hline Scenario & $\begin{array}{l}\text { Global } \\
\text { Ocean }\end{array}$ & & Atlantic and & Pacific & & $\begin{array}{l}\text { North Atlantic } \\
\text { and Pacific }\end{array}$ & $\begin{array}{l}\text { North } \\
\text { Atlantic }\end{array}$ & $\begin{array}{l}\text { North } \\
\text { Pacific }\end{array}$ & $\begin{array}{c}\text { Eastern Equatorial } \\
\text { Pacific }\end{array}$ & $\begin{array}{l}\text { Southern } \\
\text { Ocean }\end{array}$ \\
\hline Area $\left(\mathrm{km}^{2}\right)$ & $360 \times 10^{6}$ & & $47.10 \times$ & $10^{6}$ & & $435 \times 10^{3}$ & $203 \times 10^{3}$ & $232 \times 10^{3}$ & $306 \times 10^{3}$ & $160 \times 10^{3}$ \\
\hline Molar ratio of TA: $\mathrm{CO}_{2}$ & $2: 1$ & $2: 1$ & $1.5: 1 \quad 1: 1$ & $0.5: 1$ & $0.2: 1$ & $2: 1$ & $1: 1$ & $1: 1$ & $1: 1$ & $1: 1$ \\
\hline Max $\mathrm{CO}_{2}$ drawdown (ppm) & 450 & 450 & $402 \quad 287$ & 150 & 72 & 369 & 168 & 267 & 285 & 265 \\
\hline Max regional $\mathrm{pH}$ increase & - & 0.31 & $0.23 \quad 0.15$ & 0.075 & 0.029 & 0.21 & 0.10 & 0.23 & 0.23 & 0.27 \\
\hline Max global pH increase & 0.37 & 0.29 & $0.22 \quad 0.14$ & 0.073 & 0.028 & 0.18 & 0.06 & 0.11 & 0.13 & 0.13 \\
\hline
\end{tabular}

information and Table 1). In this global alkalinity enhancement scenario following the 2:1 (TA: $\left.\mathrm{CO}_{2}\right)$ molar ratio, atmospheric $\mathrm{CO}_{2}$ does not exceed $490 \mathrm{ppm}$ (compared to 1000 ppm unmitigated) when fossil fuel $\mathrm{CO}_{2}$ emissions follow the IPCC A1B scenario. Global seawater $\mathrm{pH}$ and $\Omega$ even slightly increase compared to today's values, approaching their preindustrial state. Large application area results in a uniform increase in seawater TA, $\mathrm{pH}$, and $\Omega$ over the global ocean surface. Thus, the addition of large amounts of alkalinity globally (corresponding to about 2.4 $\mathrm{Pmol} \mathrm{yr}^{-1}$ during the years 2020 2030) would substantially mitigate atmospheric $\mathrm{CO}_{2}$ and ocean acidification without environmental stress generated by elevating biogeochemical properties significantly beyond naturally occurring levels. Global natural silicate weathering contributes about $0.012 \mathrm{Pmol} \mathrm{yr}^{-1}$ [Munhoven, 2002]. Hence, an alkalinization scenario with the molar ratio $2: 1 \mathrm{TA}: \mathrm{CO}_{2}$ is equivalent to accelerating the natural weathering flux by 2 orders of magnitude. Annual world bulk production of all varieties of lime is estimated at $0.3 \mathrm{Pg} \mathrm{yr}^{-1}$ on average between the years 2006 and 2010 [The United States Geological Survey, 2011]. Assuming this is all lime, this is equivalent to 0.005 $\mathrm{Pmol} \mathrm{Ca}(\mathrm{OH})_{2} \mathrm{yr}^{-1}$. The lime production would have to be increased by much more than 2 orders of magnitude worldwide to fulfill an efficient alkalinization scenario.

[8] In further model experiments, we focus on a set of largescale regional scenarios in which TA was added over an area of about 47 million $\mathrm{km}^{2}$ in the Pacific and Atlantic Ocean covering approximately one seventh of the World Ocean (Figure 1). Cumulative fossil fuel $\mathrm{CO}_{2}$ emissions (since the year 1750) of about $1600 \mathrm{Pg} \mathrm{C}$ by the year 2100 are projected to elevate the atmospheric $\mathrm{CO}_{2}$ concentration above $900 \mathrm{ppm}$ and decrease global mean surface $\mathrm{pH}$ by about 0.4 compared to preindustrial values (Figure 2). Adding alkalinity in relatively small amounts, i.e., in proportion 0.2:1 mol mol${ }^{-1}\left(\mathrm{TA}: \mathrm{CO}_{2}\right)$, has only little effects on atmospheric $\mathrm{CO}_{2}(\max -72 \mathrm{ppm}$; Table 1$)$ and $\mathrm{pH}(<+0.03)$. Adding alkalinity in a $2: 1$ ratio would allow to keep atmospheric $\mathrm{CO}_{2}$ below $520 \mathrm{ppm}$ by the end of this century. Global mean surface $\mathrm{pH}$ would fall only by $<0.1$ (instead of 0.4 if no alkalinization is undertaken) compared to today's values, $\Omega$ would stay above preindustrial for about 100 years if TA is increased by $2.8 \mathrm{Pmol} \mathrm{yr}^{-1}$.

[9] Effects of alkalinity enhancement propagate into the ocean interior. In the present day ocean, waters shallower than about $4500 \mathrm{~m}$ depth on average are supersaturated with respect to calcite. Ocean acidification reduces $\Omega$ and by the end of the 21 st century, the global ocean below $300 \mathrm{~m}$ is projected to become undersaturated and thus corrosive for calcite (Figure 3). In our scenario with the highest mitigation effectiveness (with a molar ratio 2:1 $\mathrm{TA}: \mathrm{CO}_{2}$ ), the saturation horizon (depth at which $\Omega=1$ ) deepens by a few hundred meters during the first few centuries after the onset of alkalinization.
[10] Some technologies considered for alkalinity enhancement, such as production of $\mathrm{Ca}(\mathrm{OH})_{2}$ from quick lime obtained by decarbonation of $\mathrm{CaCO}_{3}$ have large energy and fossil fuel $\mathrm{CO}_{2}$ footprints. For instance, the heat production required to decarbonate $\mathrm{CaCO}_{3}$ to $\mathrm{Ca}(\mathrm{OH})_{2}$ would add extra $\mathrm{CO}_{2}$ emissions, e.g., leading to a doubling of global $\mathrm{CO}_{2}$ emissions in a 2:1 scenario. If the required heat could be produced from renewables, e.g., using a solar calcination technique [Nikulshina et al., 2006], only a marginal extra $\mathrm{CO}_{2}$ emission would arise in addition to the $\mathrm{CO}_{2}$ released from $\mathrm{CaCO}_{3}$ during calcination (or decarbonization). In our scenarios, $\mathrm{CO}_{2}$ emitted during production of $\mathrm{Ca}(\mathrm{OH})_{2}$ and due to the processing plus transport of materials is not considered explicitly. Instead, we ran scenarios in which $\mathrm{TCO}_{2}$ is increased alongside with increasing TA in a ratio 2:1 (TA: $\mathrm{TCO}_{2}$; Figure S4). Potential of these scenarios to mitigate atmospheric $\mathrm{CO}_{2}$ is roughly half of that calculated for scenarios in which only TA is altered. This range of model scenarios also reflects on the different effectiveness of other Ca-based alkalinity enhancement methods which inevitably boost the uptake of atmospheric $\mathrm{CO}_{2}$ and increase seawater $\mathrm{pH}$ and $\Omega$, for instance, when using $\mathrm{CaCO}_{3}$ instead of $\mathrm{Ca}(\mathrm{OH})_{2}$ or replacing half of the $\mathrm{Ca}(\mathrm{OH})_{2}$ by $\mathrm{Ca}\left(\mathrm{HCO}_{3}\right)_{2}$ (see section 1 ).

[11] Our results indicate that a large-scale regional alkalinization scenario (i.e., 2:1 mol mol ${ }^{-1} \mathrm{TA}: \mathrm{CO}_{2}$ ) would significantly perturb distributions of some key biogeochemical parameters (Figure 1). In this scenario, a rise in surface TA above $5500 \mu \mathrm{mol} \mathrm{kg} \mathrm{kg}^{-1}$ and in seawater $\mathrm{pH}$ up to 8.7 is projected in regions where alkalinity is injected. Surface $\Omega$ would rise above 30 , significantly beyond naturally occurring levels (ranging between about 4 and 6 for calcite in the modern surface ocean). Experimental manipulation of calcium concentration [Gattuso et al., 1998] showed that at aragonite saturation levels somewhat above present conditions, calcification rate in corals increased threefold; it does not increase further as aragonite saturation rises above the last glacial levels. Hence, high $\Omega$ values associated with alkalinity enhancement would imply increased biotic and abiotic precipitation of $\mathrm{CaCO}_{3}$ (which is likely to start at $\Omega$ values of 20-25) [Morse and $\mathrm{He}, 1993$ ]. As $\mathrm{CaCO}_{3}$ formation and precipitation removes alkalinity, an increase in the upper ocean precipitation rate would decrease the oceanic capacity to take up atmospheric $\mathrm{CO}_{2}$ and thus would set an upper limit for alkalinization. An elevated $\mathrm{CaCO}_{3}$ particle export flux could enhance ballasting of particulate organic carbon with possible implications for the biological pump [Klaas and Archer, 2002]. Furthermore, speciation, abundance, and toxicity of metals are a function of $\mathrm{pH}$ and water hardness and most metals are less soluble in waters with higher $\mathrm{pH}$ [Millero et al., 2009]. Also, biologically driven redox reactions involving nitrogen transformations in seawater are $\mathrm{pH}$ dependent so that largescale changes in $\mathrm{pH}$ may alter the marine nitrogen cycle 

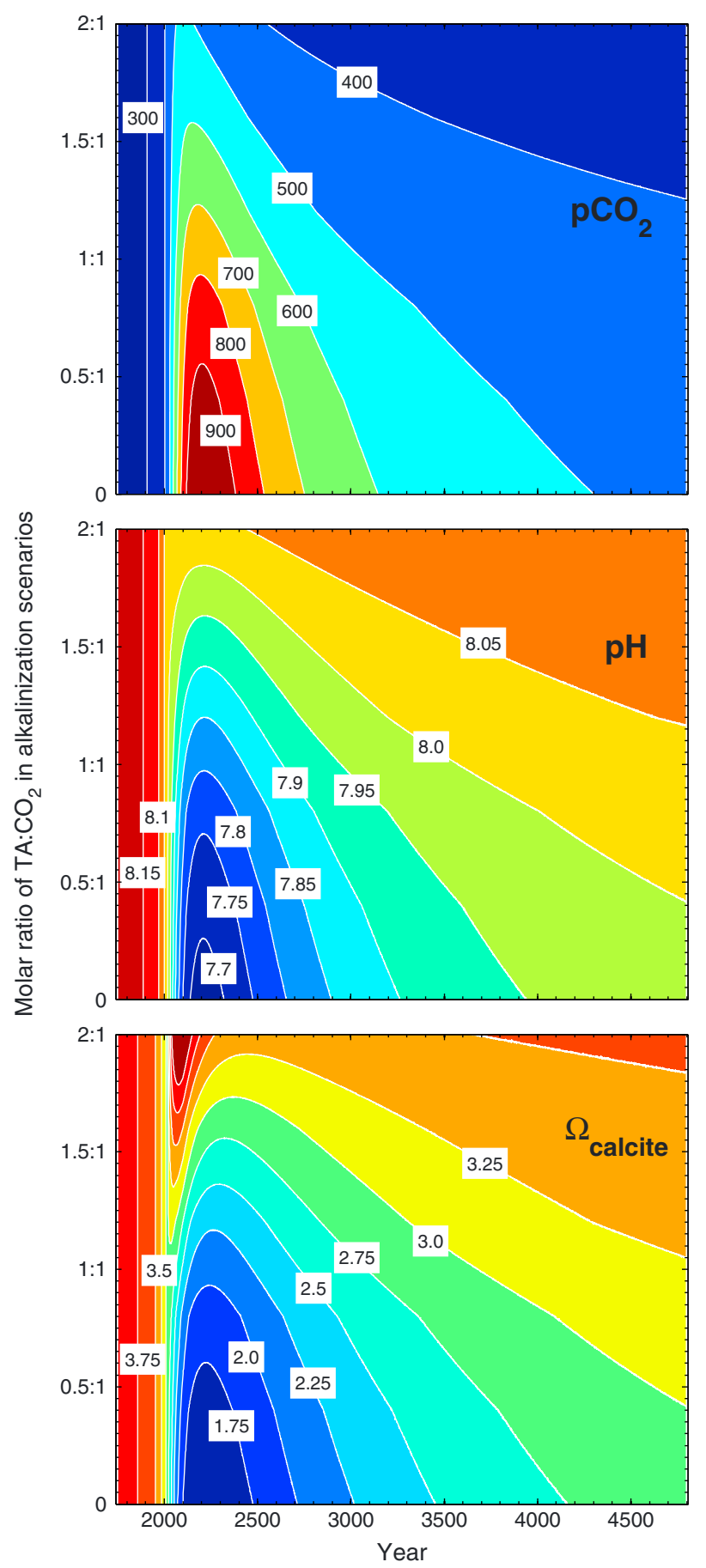

Figure 2. Mitigation potential of artificial ocean alkalinization: atmospheric $\mathrm{CO}_{2}$ concentration (in ppm), sea surface $\mathrm{pH}$, and $\Omega$ are shown by white contour lines for different alkalinization scenarios (represented in molar ratios TA: $\mathrm{CO}_{2}$ ) as a function of time.

[Kranz et al., 2010]. Although the biological effects of alkalinity enhancement have not been fully assessed across the range of marine organisms, in a recent study, Cripps et al. [2013] demonstrated that liming of seawater in treatments lead to respiratory alkalosis (a disruption of acid-base homeostasis) in crustacean species already at $\mathrm{pH} 8.46$ (with corresponding $\Omega$ of calcite values of 7.09). Such values (and higher) are projected in regions of alkalinity addition in our 2:1 TA: $\mathrm{CO}_{2}$ scenario (Figure 1). With time ocean currents redistribute the alkalized water mass over a larger volume so that they resemble their today's pattern, albeit at higher TA and $\Omega$ values (Figure S2).

\section{Potential of Artificial Ocean Alkalinization to Address Regional Impacts of Ocean Acidification}

[12] While the World Ocean is capable of taking up large amounts of $\mathrm{CO}_{2}$ [e.g., Maier-Reimer and Hasselmann, 1987; Broecker and Takahashi, 1977; Sabine et al., 2004], a combination of physical, chemical, and biological properties together with hydrodynamic conditions make certain areas of the ocean act as net sinks or net sources of atmospheric $\mathrm{CO}_{2}$ over the year [Key et al., 2004]. Colder waters can dissolve more gaseous $\mathrm{CO}_{2}$ but have a higher Revelle factor (lower buffering capacity) than warmer waters. Analogous to salinity, surface ocean TA is mainly determined by the addition or removal of freshwater via precipitation, sea ice melting, and evaporation and has a geographical gradient of about $450 \mu \mathrm{mol} \mathrm{kg}{ }^{-1}$ with higher values in the gyres in the Atlantic and Pacific Ocean (Figure 1). In further model experiments, alkalinity is added in four subregions with different hydrodynamic conditions: the sink areas in the North Pacific and the North Atlantic, and the source areas in the upwelling regions off the coast of Peru and the Southern Ocean. In these smaller-scale scenarios, alkalinity is introduced over an area of 160,000-230,000 $\mathrm{km}^{2}$. Amounts of alkalinity necessary to increase $\mathrm{pH}$ and/or $\Omega$ locally would be substantially lower compared to large-scale scenarios. Whereas seawater $\mathrm{pH}$ rises following the declining atmospheric $\mathrm{CO}_{2}$, waters not yet affected by alkalinization are transported by ocean flow and mixing. As a result, subsurface $\mathrm{pH}$ drops further and contributes to decreasing surface $\mathrm{pH}$ values in regions remote from the alkalinization sites. The increase in $\mathrm{pH}$ varies regionally (Table 1), i.e., it increases on-site and decreases in remote areas. Hence, regional alkalinity enhancement has the potential to fully mitigate ocean acidification only at the point of application. On longer time scales ( $>1000$ years), the changes in atmospheric $\mathrm{CO}_{2}$ and ocean $\mathrm{pH}$ become independent on the location of the alkalinization sites and are determined only by the amount of alkalinity added. About 1500 years after the onset of alkalinization, the global ocean surface TA approaches the TA in the unmitigated A1B scenario, whereas atmospheric $\mathrm{CO}_{2}$ and seawater $\mathrm{pH}$ differ from their unmitigated counterparts throughout the whole simulation (Figure 3).

[13] The North Atlantic had the lowest effectiveness in decreasing $\mathrm{CO}_{2}$ and increasing $\mathrm{pH}$ in our scenarious $\mathrm{pH}$ (Table 1). Even though both North Atlantic and North Pacific absorb atmospheric $\mathrm{CO}_{2}$ (on average over a year), they have different circulation regimes. Alkalinity added in the surface waters in the North Atlantic would be transported into the deep ocean, particularly in the areas of deep water formation, thus having only a small effect on the surface $\mathrm{pH}$ in this region. On the contrary, adding alkalinity to surface waters which would be longer in contact with the air above showed to be more effective in lowering of atmospheric $\mathrm{CO}_{2}$. In line with the circulation pattern and the prevailing Antarctic Circumpolar Current, alkalinization at the Southern Ocean site had the fastest and largest effect on the regional surface $\mathrm{pH}$. Alkalinity addition to the net $\mathrm{CO}_{2}$ source areas also yielded the largest mitigation effect on the global $\mathrm{pH}$. 


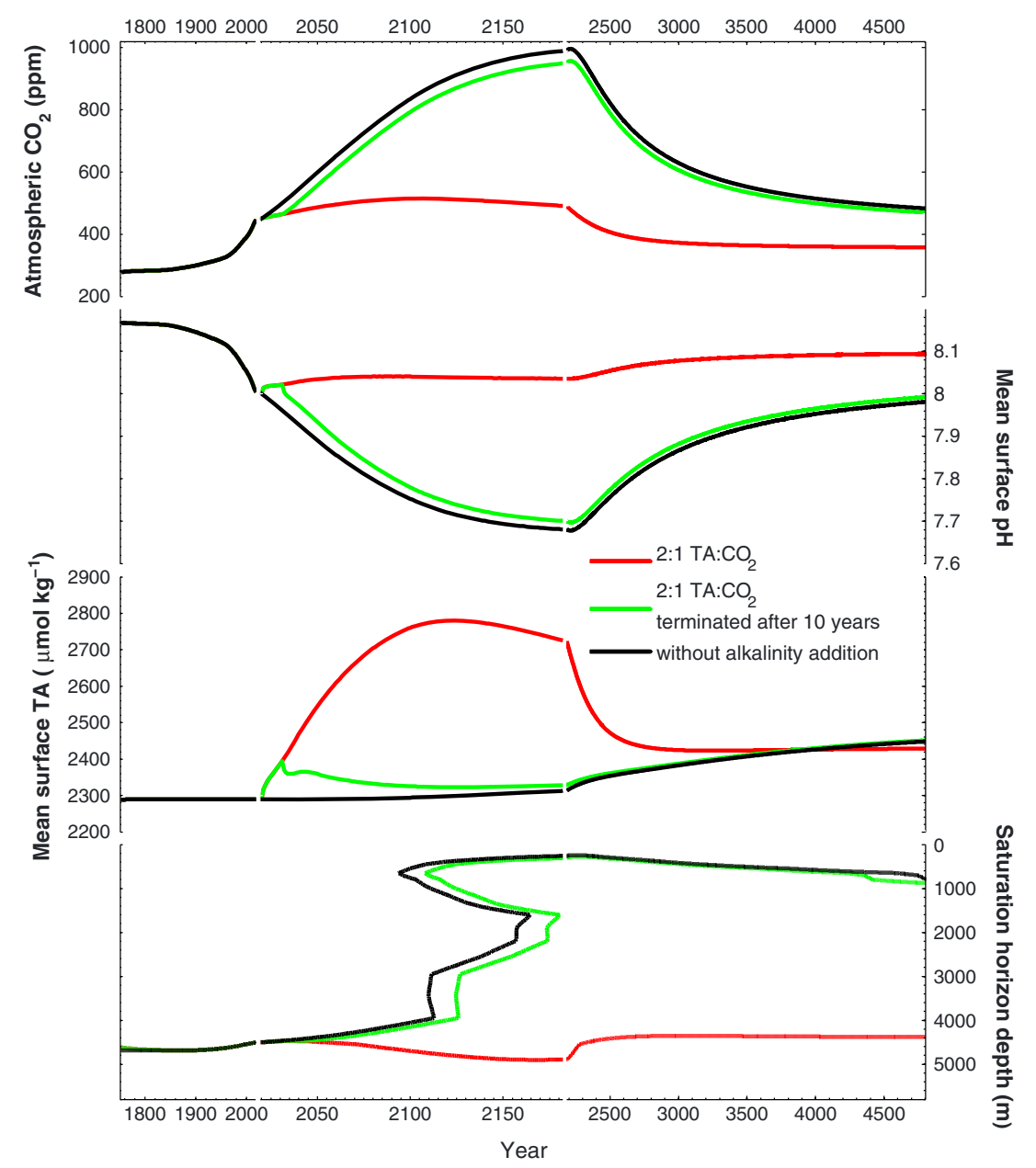

Figure 3. Temporal evolution of atmospheric $\mathrm{CO}_{2}, \mathrm{pH}$, TA, and the saturation horizon of calcite (depth at which $\Omega=1$ ) in the unmitigated A1B scenario (black), the $2: 1 \mathrm{~mol} \mathrm{~mol}^{-1} \mathrm{TA}: \mathrm{CO}_{2}$ scenario (red), and the 2:1 scenario in which alkalinization terminated after 10 years (green). Note that a broken $x$ axis has been used to zoom into the years 2020-2200.

\section{Effects of Termination of Artificial Ocean Alkalinization}

[14] While TA of the oceans does not change when $\mathrm{CO}_{2}$ is dissolved, it is projected to increase in a high $\mathrm{CO}_{2}$ world as a result of decreased production [Ilyina et al., 2009] and increased dissolution of $\mathrm{CaCO}_{3}$ (Figure 1) [Ilyina and Zeebe, 2012]. Due to slow equilibration with sediments at the ocean bottom, concomitant changes in seawater carbonate chemistry go on for several tens of thousands of years [Archer, 2005; Ridgwell and Hargreaves, 2007]. Likewise, even a short-term alkalinization would have long-lasting effects on seawater carbonate chemistry. We look at the effect of termination of alkalinization after 10 years (Figure 3). In this scenario, atmospheric $\mathrm{CO}_{2}$ decreases by $30 \mathrm{ppm}$ (in the 2:1 mol mol $\mathrm{mA}^{-1} \mathrm{TA} \mathrm{CO}_{2}$ scenario) relative to the unmitigated A1B scenario in the 21 st century. Once alkalinization has stopped, atmospheric $\mathrm{CO}_{2}$ reverts back to rising at the rate determined by the fossil fuel $\mathrm{CO}_{2}$ emissions growth. Unlike solar radiation management (using sulfate aerosols) [Niemeier et al., 2010], the effect of alkalinization is permanent (at least on the time scale of several thousands of years) and $\mathrm{CO}_{2}$ concentration remains about 10 ppm below the unmitigated scenario during the tail part of the simulation when fossil fuel $\mathrm{CO}_{2}$ emission cease. Similarly, a no-penalty termination of alkalinization holds for seawater $\mathrm{pH}$ so that it stays markedly above the unmitigated A1B scenario throughout the simulation period. Thus, alkalinization would not involve a long-term commitment.

\section{Summary}

[15] In summary, scenarios in which large amounts of alkalinity (i.e., in a ratio of 2:1 with respect to emitted $\mathrm{CO}_{2}$ ) are added over large ocean areas or even globally can boost oceanic uptake of fossil fuel $\mathrm{CO}_{2}$ from the atmosphere and avoid further ocean acidification (so that seawater $\mathrm{pH}$ and $\Omega$ do not fall below the values at the onset of alkalinization) on the global scale. Such alkalinity enhancement could drive some key biogeochemical parameters to values significantly above natural levels. Hence, while alkalinization has high mitigation potential if applied globally, large-scale regional applications can potentially have a number of environmental implications that are intrinsically difficult to predict. In the light of our results, reduction of greenhouse gas emissions is necessary to address both climate change and ocean acidification globally. On short time scales, alkalinity enhancement could target local ocean acidification mitigation allowing avoidance of large changes in surface $\mathrm{pH}$ and $\Omega$ in certain high-value ecosystems of the world ocean, e.g., in semi-enclosed basins, 


\section{ILYINA ET AL.: MODELING MITIGATION POTENTIAL OF AOA}

near coral reefs, or upwelling regions. The global decrease of atmospheric $\mathrm{CO}_{2}$ would then be considered a small side effect. The mitigation attained via alkalinity enhancement would remain so that climate does not immediately revert once this geoengineering method is no longer applied. While further research is needed to offer detailed information for knowledgeable policy decisions, our results provide the first assessment of ocean alkalinity enhancement and the concomitant longterm changes in ocean biogeochemistry based on a threedimensional ocean general circulation model.

[16] Acknowledgments. This study is a contribution to NoAA, the DFGfunded SPP 1689 “Climate Engineering: Risks, Challenges, Opportunities?" and EU FP7 projects CARBOCHANGE (grant 264879), EPOCA (grant 211384), and COMBINE (grant 226520). This is publication number A435 of the Bjerknes Centre for Climate Research and a contribution to the Centre for Climate Dynamics. GM is a Research Associate with the Belgian Fund for Scientific Research-FNRS. We thank Andy Ridgwell and an anonymous reviewer for their helpful comments

[17] The Editor thanks Andy Ridgwell and an anonymous reviewer for their assistance in evaluating this paper.

\section{References}

Archer, D. (2005), Fate of fossil fuel $\mathrm{CO}_{2}$ in geologic time, J. Geophys. Res., 110, C09S05, doi:10.1029/2004JC002625.

Broecker, W. S., and T. Takahashi (1977), Neutralization of fossil fuel $\mathrm{CO}_{2}$ by marine calcium carbonate, in The Fate of Fossil Fuel $\mathrm{CO}_{2}$ in the Oceans, edited by N. R. Andersen and A. Malahoff, pp. 213-241, Plenum Press, New York.

Caldeira, K., and G. H. Rau (2000), Accelerating carbonate dissolution to sequester carbon dioxide in the ocean: Geochemical implications, Geophys. Res. Lett., 27, 225-228.

Cripps, G., S. Widdicombe, J. I. Spicer, and H. S. Findlay (2013), Biological impacts of enhanced alkalinity in Carcinus maenas, Mar. Pollut. Bull., 71, 190-198, doi:10.1016/j.marpolbul.2013.03.015.

Feely, R. A., C. L. Sabine, K. Lee, W. Berelson, J. Kleypas, V. J. Fabry, and F. J. Millero (2004), Impact of anthropogenic $\mathrm{CO}_{2}$ on the $\mathrm{CaCO} 3$ system in the oceans, Science, 305(5682), 362-366.

Gattuso, J. P., and L. Hansson (Eds.) (2011), Ocean Acidification, Oxford Univ. Press, New York.

Gattuso, J. P., M. Frankignoulle, I. Bourge, S. Romaine, and R. W. Buddemeier (1998), Effect of calcium carbonate saturation of seawater on coral calcification, Global Planet. Change, 18, 37-46.

Harvey, L. D. D. (2008), Mitigating the atmospheric $\mathrm{CO}_{2}$ increase and ocean acidification by adding limestone powder to upwelling regions, J. Geophys. Res., 13, C04028, doi:10.1029/2007JC004373.

Ilyina, T., and R. E. Zeebe (2012), Detection and projection of carbonate dissolution in the water column and deep-sea sediments due to ocean acidification, Geophys. Res. Lett., 39, L06606, doi:10.1029/2012GL051272.

Ilyina, T., R. E. Zeebe, E. Maier-Reimer, and C. Heinze (2009), Early detection of ocean acidification effects on marine calcification, Global Biogeochem. Cycles, 23, GB1008, doi:10.1029/2008GB003278.

Intergovernmental Panel on Climate Change (IPCC) (2005), Special Report on Carbon Dioxide Capture and Storage, 442 pp., Cambridge Univ. Press, Cambridge, U. K.

IPCC (2007), Climate Change 2007: The Physical Science Basis, edited by S. Solomon et al., pp. 996, Cambridge Univ. Press, Cambridge, United Kingdom and New York, NY, USA.

Key, R. M., et al. (2004), A global ocean carbon climatology: Results from Global Data Analysis Project (GLODAP), Global Biogeochem. Cycles, 18, GB4031, doi:10.1029/2004GB002247.
Kheshgi, H. S. (1995), Sequestering atmospheric carbon dioxide by increasing ocean alkalinity, Energy, 20, 915-922.

Klaas, C., and D. E. Archer (2002), Association of sinking organic matter with various types of mineral ballast in the deep sea: Implications for the rain ratio, Global Biogeochem. Cycles, 16(4,1116), doi:10.1029/ $2001 \mathrm{~GB} 001765$.

Köhler, P., J. Hartmann, and D. A. Wolf-Gladrow (2010), Geoengineering potential of artificially enhanced silicate weathering of olivine, Proc. Natl. Acad. Sci. U.S.A., 23, 20,228-20,233.

Kranz, S., D. Wolf-Gladrow, G. Nehrke, G. Langer, and B. Rost (2010), Calcium carbonate precipitation induced by the growth of the marine cyanobacteria Trichodesmium, Limnol. Oceanogr., 55, 2563-2569.

Maier-Reimer, E., and K. Hasselmann (1987), Transport and storage of $\mathrm{CO}_{2}$ in the ocean-An inorganic ocean circulation carbon cycle model, Clim. Dyn., 2, 63-90.

Maier-Reimer, E., I. Kriest, J. Segschneider, and P. Wetzel (2005), The HAMburg Ocean Carbon Cycle Model HAMOCC 5.1-Technical Description Release 1.1, Berichte zur Erdsystemforschung, 14, Max Planck Institute for Meteorology, Hamburg, 1407 Germany, ISSN 1614-1199, 50 p., http://www.mpimet.mpg.de/fileadmin/publikationen/ erdsystem_14.pdf.

Millero, F. J., R. Woosley, B. Ditrolio, and J. Waters (2009), Effects of ocean acidification on the speciation of metals in seawater, Oceanography, 22(4), 72-85.

Morse, J. W., and S. He (1993), Influences of T, S, and $\mathrm{pCO}_{2}$ on the pseudohomogeneous precipitation of $\mathrm{CaCO} 3$ from seawater: Implications for whiting formation, Mar. Chem., 41, 291-297.

Munhoven, G. (2002), Glacial-interglacial changes of continental weathering: Estimates of the related $\mathrm{CO}_{2}$ and $\mathrm{HCO} 3$-Flux variations and their uncertainties, Global Planet. Change, 33(1-2), 155-176.

Niemeier, U., H. Schmidt, and C. Timmreck (2010), The dependency of geoengineered sulfate aerosol on the emission strategy, Atmos. Sci. Lett., 12, 189-194, doi:10.1002/asl.304.

Nikulshina, V., D. Hirscha, M. Mazzottia, and A. Steinfeld (2006), $\mathrm{CO}_{2}$ capture from air and co-production of $\mathrm{H} 2$ via the $\mathrm{Ca}(\mathrm{OH}) 2-\mathrm{CaCO} 3$ cycle using concentrated solar power-Thermodynamic analysis, Energy, 31, 1379-1389.

Rau, G. H. (2011), $\mathrm{CO}_{2}$ mitigation via capture and chemical conversion in seawater, Environ. Sci. Technol., 45, 1088-1092.

Rau, G. H., and K. Caldeira (1999), Enhanced carbonate dissolution: A means of sequestering waste $\mathrm{CO}_{2}$ as ocean bicarbonate, Energ. Convers. Manag., 40, 1803-1813.

Ridgwell, A., and J. C. Hargreaves (2007), Regulation of atmospheric $\mathrm{CO}_{2}$ by deep-sea sediments in an Earth system model, Global Biogeochem. Cycles, 21, GB2008, doi:10.1029/2006GB002764.

Ridgwell, A., T. J. Rodengen, and K. Kohfeld (2011), Geographical variations in the effectiveness and side effects of deep ocean carbon sequestration, Geophys. Res. Lett., 38, L17610, doi:10.1029/2011GL048423.

Royal Society (2009), Geoengineering the Climate: Science, Governance and Uncertainty, edited by J. Shepherd et al., 82 pp., London.

Sabine, C. L., et al. (2004), The oceanic sink for anthropogenic $\mathrm{CO}_{2}$, Science, 305, 367-371.

Schuiling, R. D., and P. Krijgsman (2006), Enhanced weathering: An effective and cheap tool to sequester $\mathrm{CO}_{2}$, Clim. Change, 74, 349-354.

Six, K. D., and E. Maier-Reimer (1996), Effects of plankton dynamics on seasonal carbon fluxes in an ocean general circulation model, Global Biogeochem. Cycles, 10, 559-583.

The United States Geological Survey (2011), 2010 Minerals Yearbook, Metals and Minerals: Lime, vol. I, 43 pp., U.S. Department of the Interior, U.S. Geological Survey, Reston, Va., http://minerals.usgs.gov/ minerals/pubs/commodity/lime/myb1-2010-lime.pdf.

Wolf-Gladrow, D. A., R. E. Zeebe, C. Klaas, A. Körtzinger, and A. G. Dickson (2007), Total alkalinity: The explicit conservative expression and its application to biogeochemical processes, Mar. Chem., 106, 287-300.

Zeebe, R. E., and D. A. Wolf-Gladrow (2001), $\mathrm{CO}_{2}$ in Seawater: Equilibrium, Kinetics, Isotopes, 346 pp., Elsevier, Amsterdam. 